\title{
HIGH BLOOM GELATIN STRENGTH FROM WHITE LEATHER SHAVINGS
}

\section{Hamed M. ELSAYED ${ }^{1 *}$, Rasha Z. ATTIA ${ }^{1}$, Ola A. MOHAMED ${ }^{1}$, Nabil H. EL-SAYED ${ }^{1}$, Saber A. IBRAHIM²*}

${ }^{1}$ Chemistry of Tanning Materials and Leather Technology Department, National Research Centre, Dokki, Cairo 12622, Egypt

${ }^{2}$ Packaging Materials Department, National Research Centre, Dokki, Cairo 12622, Egypt

Received: 18.06 .2018

Accepted: 06.12.2018

https://doi.org/10.24264/Ifj.18.4.2

\section{HIGH BLOOM GELATIN STRENGTH FROM WHITE LEATHER SHAVINGS}

ABSTRACT. Leather making process is recognized as one of the highly polluting extensive industries which generate huge amounts of solids and liquid tannery wastes. These wastes effect in severely way on the surrounding environment and human health if these polluting not well treated. The aim of this article is to obtain high bloom gelatin from white leather shavings (untanned hide shavings, WLS) via alkaline hydrolysis for improved utilization of leather waste. This research introduces a system of reusing technologies for WLS wastes including preparing gelatin, isolating collagen protein by extracting method then characterization of extracted gelatin. This article recognized to determine efficiency of the thermal and chemical treatments on the white leather waste in recovering the largest amount of gelatin with high bloom strength and a smallest amount of residue. Chemical treatments of white solid wastes by partial hydrolysis of wastes using different factors affecting on hydrolysis such as alkalis concentration, temperature and contact time were discussed. The method verified that the leather wastes can be successfully processed to the powder like leather gelatin products. It was found that the optimum conditions to obtain high bloom gelatin strength from white shaving leather wastes around 150 bloom are $4 \% \mathrm{w} / \mathrm{v} \mathrm{NaOH}, 4$ hours contact time, $250 \mathrm{rpm}$ at $50{ }^{\circ} \mathrm{C}$. KEY WORDS: alkaline hydrolysis, gelatin, high bloom strength, SEM, white leather shavings

\section{OBTINEREA GELATINEI CU PUTERE GELIFIANTĂ MARE DIN DEŞEURI DE PIELE NETĂBĂCITĂ}

REZUMAT. Industria de pielărie este recunoscută ca fiind una dintre industriile care poluează foarte mult, care generează cantităţi uriaşe de deşeuri solide şi lichide. Aceste deşeuri au efecte adverse asupra mediului înconjurător şi asupra sănătăţii umane dacă nu sunt tratate cum trebuie. Scopul acestui articol este de a obţine gelatină cu putere gelifiantă mare din deşeuri de piele netăbăcită prin hidroliză alcalină pentru o utilizare mai bună a deşeurilor de piele. Această cercetare introduce un sistem al tehnologiilor de reutilizare a deşeurilor de piele, inclusiv prepararea gelatinei, izolarea proteinei de colagen prin metoda de extracţie, apoi caracterizarea gelatinei extrase. Acest articol a avut scopul de a determina eficienţa tratamentelor termice şi chimice asupra deşeurilor de piele netăbăcită în vederea recuperării unei cantităţi mari de gelatină cu o putere gelifiantă mare şi cu o cantitate mică de reziduuri. S-au discutat tratamente chimice ale deşeurilor solide de piele netăbăcită prin hidroliza parţială a deşeurilor utilizând diferiţi factori care afectează hidroliza, cum ar fi concentraţia de baze, temperatura şi timpul de contact. Metoda a verificat faptul că deşeurile de piele pot fi prelucrate cu succes sub formă de produse din piele gelatină pulbere. Condiţiile optime pentru a obţine gelatină din deşeuri de piele netăbăcită cu putere gelifiantă mare, de 150 grade Bloom, au fost: $4 \% \mathrm{NaOH}$ $\mathrm{w} / \mathrm{v}$, timp de contact 4 ore, $250 \mathrm{rpm}$ la $50^{\circ} \mathrm{C}$.

CUVINTE CHEIE: hidroliză alcalină, gelatină, putere gelifiantă mare, SEM, deşeuri de piele netăbăcită

OBTENTION D'UNE GÉLATINE À HAUTE RÉSISTANCE À L'ENFONCEMENT À PARTIR DE DÉCHETS DE PEAU NON TANNÉE

RÉSUMÉ. L'industrie du cuir est reconnue comme l'une des vastes industries qui polluent beaucoup, générant d'énormes quantités de déchets solides et liquides. Ces déchets ont des effets néfastes sur l'environnement et la santé humaine s'ils ne sont pas traités correctement. Le but de cet article est d'obtenir une gélatine à haute résistance à l'enfoncement à partir de déchets de peau non tannée par l'hydrolyse alcaline pour une meilleure utilisation des déchets de cuir. Cette recherche introduit un système de réutilisation des technologies de traitement des déchets de cuir, notamment la préparation de gélatine, l'isolement de protéines de collagène par une méthode d'extraction, et puis la caractérisation de la gélatine extraite. Cet article a eu le but de déterminer l'efficacité des traitements thermiques et chimiques sur les déchets de peau non tannée afin de récupérer une grande quantité de gélatine à haute résistance à l'enfoncement et une faible quantité de résidus. Les traitements chimiques des déchets solides de peau non tannée ont été discutés par l'hydrolyse partielle des déchets en utilisant divers facteurs qui influent sur l'hydrolyse, tels que la concentration des alcalis, la température et le temps de contact. La méthode a permis de vérifier que les déchets de peau pouvaient être traités avec succès sous forme de produits à base de poudre de peau en tripe. Les conditions optimales pour obtenir de la gélatine à 150 degrés Bloom à partir de déchets de peau non tannée ont été: $4 \% \mathrm{NaOH}$ poids/volume, temps de contact 4 heures, $250 \mathrm{tr} / \mathrm{min}$ à $50^{\circ} \mathrm{C}$.

MOTS CLÉS : hydrolyse alcaline, gélatine, haute résistance à l'enfoncement, MEB, déchets de peau non tannée

* Correspondence to: Hamed M. ELSAYED, Chemistry of Tanning Materials and Leather Technology Department, National Research Centre, Dokki, Cairo 12622, Egypt, hamed_sci@yahoo.com; Saber A. IBRAHIM, Packaging Materials Department, National Research Centre, Dokki, Cairo 12622,Egypt, saberam2000@yahoo.com 


\section{INTRODUCTION}

Leather industry generates a huge amount of solid and liquid tannery wastes during the hide tanning process that produces leather as a supply for shoes, automotive and furniture markets. Environmental risk challenges arise from the nature and the wastes discharged from leather processing. The main part of leather wastes is the hide collagen structure. The leather making process generates large quantities of solid and liquid wastes, one metric ton of rawhide produces on an average 200-400 $\mathrm{kg}$ of tanned leather and a range of $600-800 \mathrm{~kg}$ of solid wastes and an average consumption of 45$50 \mathrm{~m} 3$ of waste liquors. In these process stages, solid wastes generated from leather industry are classified as 1st wastes from untanned hides or skins (white shavings, fleshing wastes) $80 \%$ of solid wastes $(500-600 \mathrm{~kg}), 2$ nd wastes from tanned leather (chrome shaving, buffing dust) $150 \mathrm{~kg}, 3 \mathrm{rd}$ wastes from finished and dyed leather (trimmings) 20-30 kg [1, 2].

The problems, solid protein wastes, have admittedly received more attention however; these have been mostly disposed until now to landfill or glue production. Many cleaner processing approaches aimed at reduction of liquid and solid wastes proved to be economically and environmentally beneficial [3-6]. Leather wastes divided into leather waste from tanneries, trimmings from leather goods factories and trimmings from the old leather products. The leather wastes from tanneries are divided into white leather wastes, chrome-containing leather wastes and dyestuff-containing leather wastes. The major part of leather wastes is protein. If protein and other unspent chemicals not utilized or treated correctly they cause severe environmental problems threatening the sustainability of leather making. Various useful products (glue, gelatin, artificial fibrous leathers, and collagen hydrolysate) can be extracted from leather wastes. The best way for their removal is to recover soluble proteins that may have a commercial use. A number of authors have reported about chemical and enzymatic treatment of leather waste [7-9].
Approximately $80 \%$ of dry matter of the hide or skin is made up of complex nitrogenous organic compound known as proteins. Collagen is the ultimate plentiful insoluble protein of animal origin, comprising about $29 \%$ of total protein. It is the major protein of skin, tendon, cartilage, bone, and white fibrous connective tissue in mammals. Collagen extracted from the previous materials is used for clarifying beverages, in cosmetics, in casing for meat products and in a host of biomedical applications. Medical applications of collagen include use in drug delivery systems, sponges for burns and wound and in tissue engineering [10].

Gelatin is a high molecular weight polypeptide derived from collagen; it is obtained by denaturation and solubilization of collagen $[11,12]$ which is derived from pigskins and bovine hides, bones and fish skin. To produce gelatin, collagen is heated in either acidic or basic solutions to break the covalent bonds between the rods and solubilize the protein. The treatment also separates the polypeptides and hydrolyzes some of the polymer chains. Gelatin quality is measured by Bloom units $[13,14]$.

There are three methods of gelatin production: acid, alkali, enzymatic processes due to soaking and autoclaving processes. The most widespread methods are acid and alkaline processing followed by heating in water. Acid and base processes produce gelatins commonly point as Type $A$ and Type $B$, respectively. Following these extraction processes [15-18], gelatin is dried to form coarse granules, fine powders, or thin sheets, which are odorless, tasteless, and yellowish in color. Over many years, gelatin has been an important biopolymer used widespread in food pharmaceutical industries. Commonly, it is used as transparent dessert jelly, but it is widely used in pastry, dessert, factories of meat products and dairy products [19-22].

The best way for their removal is to recover soluble proteins that may have commercial use. This paper deals with one of the major environmental problems of the huge manufacture in Egypt (leather industry). Approximately $80 \%$ of leather solid wastes is generated during pretanning processes in beam 
house operations. Untanned trimmings and white leather wastes have negative effects on soil and water resources of the surroundings due to the bad smell produced during their putrefaction and their dangerous chemical contents. In Egypt, production of glue is the only use for white leather shavings. In this research article, production of gelatin with high bloom strength from white leather shavings by different alkalis is our target. Alkali treatment is suitable for more complex collagen as in bovine hides, the purpose of the alkali treatment is destroying chemical crosslinks fiber bundle present in collagen.

Alkali chemical treatments of WLS by partial hydrolysis of wastes using different alkalis $(\mathrm{NaOH}, \mathrm{KOH}, \mathrm{LiOH})$ and different factors affecting hydrolysis such as alkalis concentration (2-10\% $\mathrm{w} / \mathrm{v})$, contact time (1-6 h) and temperature (40$90^{\circ} \mathrm{C}$ ) were studied.

\section{EXPERIMENTAL}

\section{Materials and Methods}

\section{Materials}

White leather wastes were supplied by tannery from Misr-El-Kadima, Cairo, Egypt. Sodium hydroxide, lithium hydroxide and potassium hydroxide are used as received. All reagents were analytically pure according to the grade of national reagent purity standards.

\section{Methods}

The purpose of this research is to recover gelatin from the white leather waste to be used in many applications [21-26]. The study also aimed at evaluation of the different parameters affecting on white leather shavings hydrolysis. White shavings with a $\mathrm{pH}$ of 3.8 after basification were obtained from a commercial tannery. The shavings were soaked in $5 x$ their weight of water for cleaning.

Factors Affecting on the Hydrolysis of White Leather Shavings (WLS)

There are different factors affecting on hydrolysis process of WLS by different alkalis $(\mathrm{NaOH}, \mathrm{KOH}, \mathrm{LiOH})$ have been studied systematically such as concentration of different alkalis, contact time and temperature.

\section{Effect of Different Concentration of Alkalis \\ (Optimum Condition of Alkalis)}

The effect of concentration of different alkalis on the hydrolysis of WLS studied as follows: White shavings (20 g) were put into a $250 \mathrm{~mL}$ flask and $80 \mathrm{~mL}$ of water was added, together with 2-10\% w/v of alkalis $(\mathrm{LiOH}, \mathrm{NaOH}$, $\mathrm{KOH}$ ) equivalent to (1-2.5 mol/L). Then, the flask was put into a water bath at $70{ }^{\circ} \mathrm{C}$ and $200 \mu \mathrm{L}$ surfactant, $250 \mathrm{rpm}$, for $6 \mathrm{~h}$, the solution was then left to cool down.

\section{Effect of Time on the Hydrolysis (Optimum Condition of Time)}

The effect of time on the hydrolysis of WLS studied as follows: white shavings (20 g) were put into a $250 \mathrm{~mL}$ flask and $80 \mathrm{~mL}$ of water was added, together with optimum condition of concentration of alkalis. Then, the flask was put into a water bath at $70{ }^{\circ} \mathrm{C}$ and $200 \mu \mathrm{L}$ surfactant, $250 \mathrm{rpm}$, different shaking time from $3 \mathrm{~h}$ up to 8 $h$, the solution was then left to cool down.

\section{Effect of Temperature on the Hydrolysis (Optimum Condition of Temperature)}

The effect of temperature on the hydrolysis of WLS studied as follows: white shavings ( $20 \mathrm{~g}$ ) were put into a $250 \mathrm{~mL}$ flask and $80 \mathrm{~mL}$ of water was added, together with optimum condition of concentration of alkalis. Then, the flask was put into a water bath at different temperature from $50-90^{\circ} \mathrm{C}$ and $200 \mu \mathrm{L}$ surfactant, $250 \mathrm{rpm}$, optimum condition of time, the solution was then left to cool down.

\section{Separation of Gelatin}

After hydrolysis of white leather shavings in each of parameters used (conc. of alkali, hydrolysis time, temperature), the extracted gelatin poured into sintered glass filter grade 4 for filtration. The residual solid white cake was washed twice with water for adjusting $\mathrm{pH}$ at 7 and then the cake was put into a Teflon mold in a drying oven for complete dryness. The dried 
gelatin was ground for obtaining gelatin powder for further characterization.

\section{Determination the Properties of the White Leather Wastes and Extracted Gelatin}

\section{Determination of Moisture}

Osborne punch was used to cut samples for moisture. The samples were weighed into dry, tared porcelain dishes. The samples were dried for $17 \mathrm{~h}$ at $105^{\circ} \mathrm{C}$. The samples were cooled in a desiccator, weighed and the percent moisture determined. $5 \mathrm{~g}$ of sample were accurately weighted in a tared dish, and then heated at $105{ }^{\circ} \mathrm{C}$ for three hours in air-oven at which the temperature was as uniform as possible; the dish was allowed to cool in a desiccator, and then weighted. The process of heating, cooling and weighting was repeated till constant weight, the moisture content is defined as the percentage loss in weight of the sample.

$\%$ moisture $=(\mathrm{W} 1-\mathrm{W} 2) \times 100 / \mathrm{W} 1$

Where: $\quad$ W1 $=$ weight of the sample before drying.

$$
\text { W2 = weight of the sample after drying. }
$$

\section{Determination of Ash}

The dried samples were ashed at $600{ }^{\circ} \mathrm{C}$ for two hours then cooled in a desiccator and weighed to determine ash content and percent volatile substance calculated on a moisture-free basis. In a burnt platinum crucible about $5 \mathrm{~g}$ of sample was accurately weighted, the sample was carefully ignited in a muffle furnace at about $600{ }^{\circ} \mathrm{C}$ for about 2 hours. Finally the crucible with its contents was cooled in a desiccator and weighted. The ignition, cooling and weighting were repeated till constant weight.

$\%$ ash $=\mathrm{Wt}$. of residue $\times 100 / \mathrm{Wt}$. of original fat

Determination of Total Kjeldahl Nitrogen (TKN)

TKN was determined by the semi-micro Kjeldahl method. Solid samples weighed to the nearest $50 \mathrm{mg}$ and liquid samples measured to $1 \mathrm{~mL}$ and transferred to a $30 \mathrm{~mL}$ digestion flask. Digestion catalyst $(1.2 \mathrm{~g})$, a few boiling chips and sulfuric acid $(2 \mathrm{~mL})$ added. The samples were digested for two hours. The samples were carefully transferred to the filling funnel and $\mathrm{NaOH}$ solution $(10 \mathrm{~mL})$ will be added. The mix was distilled to a $125 \mathrm{~mL}$ Erlenmeyer flask containing boric acid saturated solution $(10 \mathrm{~mL})$. The samples were titrated with standardized $\mathrm{HCl}$ to the gray endpoint.

\section{Determination of Fat}

For fat determination, samples were weighed into appropriate flasks and $6 \mathrm{~N} \mathrm{HCl}(75$ $\mathrm{mL}$ ) added. The samples were hydrolyzed for $2 \mathrm{~h}$. The hydrolysate was transferred to a separating funnel and the fat was extracted with chloroform or petroleum ether. The chloroform layer was put in dry, tared crystallizing dishes, the chloroform evaporated and the samples were held at $60{ }^{\circ} \mathrm{C}$ for $16 \mathrm{~h}$. The samples were cooled in a desiccator and then weighed.

\section{pH Measurement of Leather Waste}

The tests for the determination of the initial $\mathrm{pH}$ value were accomplished as follows: 5 $\mathrm{g}$ of white shavings sample was placed in $100 \mathrm{~mL}$ of distilled water at room temperature during two hours with agitation. After decantation without filtration of soluble matter, proceed to the determination of the $\mathrm{pH}$ of the prepared liquor using the $\mathrm{pH}$-meter.

\section{pH Measurement of Gelatin}

The British Standard was adapted and one gram of gelatin sample was dissolved in $100 \mathrm{~mL}$ warm distilled water. The solution was cooled to $25^{\circ} \mathrm{C}$ and the $\mathrm{pH}$ was measured with a standard $\mathrm{pH}$ meter.

\section{Yield of Gelatin}

The yield of extracted gelatin obtained was determined as follows:

Yield $(\%)=($ dry weight of the gelatin/dry weight of white leather shavings) $\times 100 \%$ 


\section{Characterization}

\section{Determination of Gel Strength}

The gel strength (Bloom) was determined according to British Standard 757:1975 method (BSI, 1975), by using a texture analyzer (CT3 Brookfield, USA). A solution containing $6.67 \%$ $(\mathrm{w} / \mathrm{v})$ gelatin was prepared by mixing $7.50 \mathrm{~g}$ of gelatin and $105 \mathrm{~mL}$ of distilled water in a Bloom bottle with stopper. The mixture was swirled and left to stand at room temperature for $3 \mathrm{~h}$, allowing the gelatin to absorb water and swell. The Bloom bottles were then transferred to a water bath maintained at $65{ }^{\circ} \mathrm{C}$ and held for 25 min with occasional swirling to dissolve the gelatin. The bottles were taken out of the water bath, allowed to cool for $15 \mathrm{~min}$ at room temperature and then placed in a cold-water bath (Brookfield gelatin bath system, model TC-550MX refrigerated bath) maintained at $10{ }^{\circ} \mathrm{C}$ and held at this temperature for $18 \mathrm{~h}$ before the determination of the gel strength. The Bloom bottle was placed centrally under the plunger (Delrin probe, which is clear acrylic AOAC and GMA cylinder with sharp edge; TA10, $12.7 \mathrm{~mm}$ diameter) of the instrument. The Bloom strength was determined with a load cell of $10 \mathrm{~kg}$ and crosshead speed of $0.5 \mathrm{~mm} / \mathrm{s}$. The maximum force $(\mathrm{g})$ was determined when the probe penetrated to a depth of $4 \mathrm{~mm}$ into the gel.

Fourier Transform Infrared Spectroscopy (FTIR)

FTIR spectra were taken with a Nexus 670 FTIR spectroscopy (Nicolet, United States) over the range of $400-4000 \mathrm{~cm}-1$ with a resolution of $4 \mathrm{~cm}-1$; the $\mathrm{KBr}$ disk technique was applied.

\section{Dynamic Light Scattering (DLS)}

The particle size investigation of the aqueous dispersions was carried out with Zetasizer Nano S (Malvern Instr., UK) equipped with a monochromatic He-Ne laser lamp $(\lambda=633$ $\mathrm{nm}$ ) as light source (ALV GmbH, Germany) at an angle of $173^{\circ}$. All measurements of dispersed samples were carried out in disposable cuvettes.
X-Ray Fluorescence (XRF)

It used to identify and determine the concentrations of elements in solid, powdered and liquid samples. XRF is capable of measuring all elements from Beryllium to Uranium and beyond levels often below one part per million. $\mathrm{X}$-ray fluorescence was carried out using Axios, WD-XRF sequential spectrometer. Sample was crushed then ground in Herzog mill to powder, then sieved through $0.063 \mathrm{~mm}$ sieve. The samples were prepared as pressed disks, through mixing $7 \mathrm{~g}$ of fine powder of each sample with $1.6 \mathrm{~g}$ of binding wax in small mill, at $380 \mathrm{rpm}$, for one minute. Sample was kept in standard aluminum cup, pressed in automatic machine less than $130 \mathrm{KN}$, the yield disk spacemen was used in qualitative and quantitative analysis of elements.

High Performance Liquid Chromatography, HPLC Amino Acid Analyzer

HPLC consists of pump for pumping of mobile phase (liquid), Octocatyl silica column (C18-column). It provided with photodiode UV detector. It is used for determination of bulky organic compounds. Liquid chromatography 300, amino acid analyzer - Eppendorf, Germany, and flow rate: $0.2 \mathrm{~mL} \backslash \mathrm{min}$, pressure of buffer from $0-50$ bar, pressure of reagent to 0-150 bar, reaction temp $123^{\circ} \mathrm{C}$, was used for amino acid analysis.

Preparation of sample to amino acids analysis:

1 - $1 \mathrm{~g}$ of gelatin was weighed in a hydrolysis tube, then $1 \mathrm{~mL}$ of $6 \mathrm{~N} \mathrm{HCL}$.

2 - The solution was frozen and evacuated from the tube with vacuum pump.

3 - The hydrolysis tube was closed by melting the glass with a suitable gas-burner.

4 - Depending on original material, hydrolysis was carried out in an oven with a uniform temperature distribution of $110{ }^{\circ} \mathrm{C}$ for 24 hours, then the tube was cooled down in an ice-bath after hydrolysis. Afterwards, the solution was centrifuged in order to precipitate insoluble components.

5 - Centrifuged solution was evaporated at approximately $40{ }^{\circ} \mathrm{C}$ in a rotary evaporator. 
6 - The sample was dissolved with 1-2 mL of sample diluting buffer; then the sample was ready for analysis.

\section{Thermal Gravimetric Analysis (TGA)}

Thermal analysis was studied with a Perkin Elmer thermogravimetric analyzer (rate $=10{ }^{\circ} \mathrm{C}$ ) min) from room temperature to $600{ }^{\circ} \mathrm{C}$ at the National Research Center of Egypt.

\section{Differential Scanning Calorimetry (DSC)}

DSC was carried out in a TA Instruments Q100 to determine glass transitions $(\mathrm{Tg})$, crystallization temperatures (Tc) and melting points $(\mathrm{Tm})$. The thermal history was erased during the first run at a high heating rate up to $200{ }^{\circ} \mathrm{C}$, followed by cooling cycle to $-50^{\circ} \mathrm{C}$. After that, the heating rate was modulated $\pm 1.0^{\circ} \mathrm{C}$ min-1 with heating rate $5.0{ }^{\circ} \mathrm{C}$ min-1 to $200{ }^{\circ} \mathrm{C}$. According to ASTM D 3418, Tg was calculated as the midpoint temperature.

\section{Scanning Electron Microscopy (SEM)}

SEM is thus a useful technique for evaluating the effects of various treatments on the leather surface and it can be used to assess the penetration of the copolymer through leather and onto the hierarchy of the structure. Leather samples $(1 \mathrm{~cm} 2)$ were subjected to sputter coating with gold ions which acted as a conducting medium during scanning, and observed using a Philips Quanta 250 electron microscope.

\section{RESULTS AND DISCUSSION}

Characterization of White Leather Shaving (WLS)

It is very important to characterize the WLS before hydrolysis for obtaining extracted content was in the range $0.39-0.5 \%$. All the percentage represented in a dry basis except for moisture.

Table 1: Properties of white leather shaving

\begin{tabular}{cc}
\hline Characteristic & Mean Value* \\
\hline $\mathrm{pH}$ & $4 \pm 0.3$ \\
Ash content & $2.8 \pm 0.2 \%$ \\
Moisture content & $11 \pm 2 \%$ \\
Nitrogen content & $14 \pm 1 \%$ \\
Fat content & $0.55 \pm 0.2 \%$ \\
\hline
\end{tabular}

Mean Value* \pm SD triplicate analysis

\section{Chemical Hydrolysis of White Leather Shavings (WLS)}

\section{Effect of Different Concentration of Alkalis}

The effect of concentration of different alkalis on the hydrolysis of WLS was studied, for obtaining optimum conditions of conc. of alkalis which is a step growth for further parameters. Table 2 showed the effect of different concentrations on the gelatin extraction from WLS. The experimental results proved that as the percent of conc. of alkalis increases, the percent of the hydrolysable protein increases, where at $2 \% \mathrm{w} / \mathrm{v}$ conc. of alkalis the WLS were not completely hydrolyzed and at $4 \% \mathrm{w} / \mathrm{v}, 6 \%$ $\mathrm{w} / \mathrm{v}$ conc. of alkalis is adequate and enough for obtaining gelatin with good bloom strength but at $8 \% \mathrm{w} / \mathrm{v}$ and $10 \% \mathrm{w} / \mathrm{v}$ conc. of alkalis waste is completely hydrolyzed to hydrolysable protein.

Table 2: The effect of different concentrations on the gelatin extraction from white leather shavings (WLS)

\begin{tabular}{|c|c|c|c|c|c|c|c|c|c|}
\hline \multirow[b]{2}{*}{ Conc. \% } & \multicolumn{3}{|c|}{$\mathrm{NaOH}$} & \multicolumn{3}{|c|}{$\mathrm{KOH}$} & \multicolumn{3}{|c|}{$\mathrm{LiOH}$} \\
\hline & $\begin{array}{c}\text { Bloom } \\
\text { G }\end{array}$ & $\begin{array}{l}\text { Viscosity } \\
\text { Poise }\end{array}$ & $\begin{array}{c}\text { Yield weight } \\
\%\end{array}$ & $\begin{array}{c}\text { Bloom } \\
\text { G }\end{array}$ & $\begin{array}{c}\text { Viscosity } \\
\text { Poise }\end{array}$ & $\begin{array}{c}\text { Yield weight } \\
\%\end{array}$ & $\begin{array}{c}\text { Bloom } \\
\text { G }\end{array}$ & $\begin{array}{l}\text { Viscosity } \\
\text { Poise }\end{array}$ & $\begin{array}{c}\text { Yield weight } \\
\%\end{array}$ \\
\hline 2 & ----- & ----- & ----- & ----- & ----- & ----- & ----- & ----- & ----- \\
\hline 4 & $160 \pm 5$ & $120 \pm 4$ & $80 \pm 2$ & $140 \pm 5$ & $163 \pm 4$ & $79 \pm 3$ & $135 \pm 4$ & $160 \pm 2$ & $79 \pm 3$ \\
\hline 6 & $100 \pm 4$ & $80 \pm 5$ & $70 \pm 3$ & $110 \pm 6$ & $150 \pm 6$ & $70 \pm 2$ & $111 \pm 4$ & $120 \pm 3$ & $71 \pm 2$ \\
\hline 8 & $80 \pm 6$ & $65 \pm 3$ & $50 \pm 2$ & $70 \pm 3$ & $90 \pm 8$ & $52 \pm 4$ & $76 \pm 6$ & $60 \pm 1$ & $55 \pm 4$ \\
\hline 10 & $40 \pm 7$ & $55 \pm 6$ & $20 \pm 4$ & $30 \pm 7$ & $50 \pm 4$ & $27 \pm 6$ & $35 \pm 8$ & $40 \pm 4$ & $25 \pm 5$ \\
\hline
\end{tabular}

-----Not enough hydrolysis

Mean Value \pm SD triplicate analysis 
From Table 2, it is obvious that, $4 \% \mathrm{w} / \mathrm{v}$ conc. of alkalis is the best concentration for gelatin extraction and it gives good viscosity and bloom values. At $2 \% \mathrm{w} / \mathrm{v}$ conc. of alkalis there is not enough hydrolysis to the shavings. Over 6 $\% \mathrm{w} / \mathrm{v}$ conc. of alkalis there is a decrease in the bloom and viscosity values, due to the hydrolysis of the collagen fibers, yielding mixture of free amino acids and hydrolysable protein. High concentration of alkaline materials decreased the gelatin yield and gel strength $[27,28]$. In conclusion, $4 \% \mathrm{w} / \mathrm{v}$ conc. of all alkalis is the best concentration for gelatin extraction because it gives good viscosity and high bloom values which is very important in case of application in the further part of the research especially in biodegradable packaging.

Effect of Extraction Time on the Hydrolysis of White Leather Shavings (WLS)

The time of extraction is a very important parameter for studying the hydrolysis of WLS for saving money for industrial application. The data was recorded in Table 3. The experimental results proved that as time increased the gel strength increased up to $4 \mathrm{~h}$ after that it tends to decrease.

From Table 3 it is obvious that, $4 \mathrm{~h}$ extraction time is the optimum time required for gelatin extraction, besides high viscosity and good bloom values. At $3 \mathrm{~h}$ extraction time is not enough time to yield acceptable bloom and viscosity. However, over $5 \mathrm{~h}$ the extracted gelatin was hydrolyzed resulting in weak bloom and viscosity, longer extraction times give very low yield. Extracted gelatin has low gel strength and viscosity due to excessive damage and breaking down the collagen fractures with longer heating and possibly extraction of hydrolysable proteins. In conclusion, $4 \mathrm{~h}$ is the best time for gelatin extraction because it gives good viscosity and bloom values.

Table 3: Effect of time on the hydrolysis of white leather shavings (WLS)

\begin{tabular}{|c|c|c|c|c|c|c|c|c|c|}
\hline \multirow{2}{*}{$\begin{array}{l}\text { Extraction } \\
\text { time } \\
\text { Hours }\end{array}$} & \multicolumn{3}{|c|}{$\mathrm{NaOH}$} & \multicolumn{3}{|c|}{$\mathrm{KOH}$} & \multirow[b]{2}{*}{$\begin{array}{c}\text { Bloom } \\
\text { G }\end{array}$} & \multirow[b]{2}{*}{$\begin{array}{c}\text { Viscosity } \\
\text { Poise }\end{array}$} & \multirow{2}{*}{$\begin{array}{c}\mathrm{LiOH} \\
\text { Yield weight } \\
\%\end{array}$} \\
\hline & $\begin{array}{c}\text { Bloom } \\
\text { G }\end{array}$ & $\begin{array}{l}\text { Viscosity } \\
\text { Poise }\end{array}$ & $\begin{array}{c}\text { Yield weight } \\
\%\end{array}$ & $\begin{array}{c}\text { Bloom } \\
\text { G }\end{array}$ & $\begin{array}{l}\text { Viscosity } \\
\text { Poise }\end{array}$ & $\begin{array}{c}\text { Yield weight } \\
\%\end{array}$ & & & \\
\hline 3 & ---- & ---- & ---- & ---- & ---- & --- & ---- & ---- & ---- \\
\hline 4 & $155 \pm 6$ & $140 \pm 7$ & $78 \pm 6$ & $160 \pm 3$ & $135 \pm 4$ & $77 \pm 4$ & $140 \pm 6$ & $150 \pm 6$ & $78 \pm 4$ \\
\hline 5 & $125 \pm 5$ & $100 \pm 5$ & $77 \pm 5$ & $130 \pm 5$ & $100 \pm 8$ & $65 \pm 4$ & $120 \pm 5$ & $89 \pm 7$ & $66 \pm 3$ \\
\hline 6 & $80 \pm 6$ & $90 \pm 4$ & $34 \pm 4$ & $90 \pm 7$ & $80 \pm 6$ & $26 \pm 3$ & $70 \pm 7$ & $65 \pm 4$ & $27 \pm 4$ \\
\hline 7 & $40 \pm 8$ & $30 \pm 8$ & $13 \pm 7$ & $30 \pm 6$ & $40 \pm 4$ & $10 \pm 6$ & $30 \pm 6$ & $20 \pm 7$ & $15 \pm 5$ \\
\hline
\end{tabular}

--- = Not enough hydrolysis

Mean Value \pm SD triplicate analysis

Effect of Temperature on the Hydrolysis of White

WLS. Table 4 show the effect of temperature on Leather Shavings (WLS) the hydrolysis of white leather shavings.

The thermal effect is very efficient parameter in case of studying the hydrolysis of

Table 4: Effect of temperature on the hydrolysis of white leather shavings (WLS)

\begin{tabular}{|c|c|c|c|c|c|c|c|c|c|}
\hline \multirow{2}{*}{$\begin{array}{c}\text { Extraction } \\
\text { temperature } \\
{ }^{\circ} \mathrm{C}\end{array}$} & \multicolumn{3}{|c|}{$\mathrm{NaOH}$} & \multicolumn{3}{|c|}{$\mathrm{KOH}$} & \multicolumn{3}{|c|}{$\mathrm{LiOH}$} \\
\hline & $\begin{array}{c}\text { Bloom } \\
\text { G }\end{array}$ & $\begin{array}{l}\text { Viscosity } \\
\text { Poise }\end{array}$ & $\begin{array}{c}\text { Yield weight } \\
\%\end{array}$ & $\begin{array}{c}\text { Bloom } \\
\text { G }\end{array}$ & $\begin{array}{l}\text { Viscosity } \\
\text { Poise }\end{array}$ & $\begin{array}{c}\text { Yield weight } \\
\%\end{array}$ & $\begin{array}{c}\text { Bloom } \\
\text { G }\end{array}$ & $\begin{array}{l}\text { Viscosity } \\
\text { Poise }\end{array}$ & $\begin{array}{c}\text { Yield weight } \\
\%\end{array}$ \\
\hline 40 & ---- & ---- & ---- & ---- & ---- & ---- & ---- & ---- & ---- \\
\hline 50 & $160 \pm 4$ & $120 \pm 4$ & $79 \pm 3$ & $140 \pm 4$ & $163 \pm 7$ & $78 \pm 2$ & $130 \pm 6$ & $160 \pm 5$ & $76 \pm 2$ \\
\hline 60 & $130 \pm 3$ & $100 \pm 5$ & $61 \pm 4$ & $120 \pm 6$ & $117 \pm 5$ & $60 \pm 3$ & $99 \pm 3$ & $120 \pm 4$ & $84 \pm 3$ \\
\hline 70 & $100 \pm 6$ & $80 \pm 3$ & $40 \pm 5$ & $100 \pm 8$ & $83 \pm 5$ & $43 \pm 4$ & $74 \pm 4$ & $90 \pm 3$ & $63 \pm 4$ \\
\hline 80 & $50 \pm 7$ & $56 \pm 5$ & $23 \pm 7$ & $80 \pm 5$ & $62 \pm 8$ & $24 \pm 6$ & $60 \pm 4$ & $66 \pm 7$ & $46 \pm 2$ \\
\hline 90 & $40 \pm 7$ & $34 \pm 7$ & $13 \pm 8$ & $50 \pm 7$ & $30 \pm 6$ & $12 \pm 8$ & $40 \pm 4$ & $36 \pm 8$ & $20 \pm 8$ \\
\hline
\end{tabular}


The experimental results proved that as temperature increased there will be an extensive increase in the hydrolysable protein up to 90 ${ }^{\circ} \mathrm{C}$. From Table 4 , it is obvious that $50{ }^{\circ} \mathrm{C}$ is the optimum extraction temperature required as it gave high viscosity and good bloom values. At temperature lower than $50^{\circ} \mathrm{C}$ solubility of gelatin decreases, so the yield was decreased. However over $60^{\circ} \mathrm{C}$ the extracted gelatin was affected by increasing temperature and hydrolyzed to free amino acids. Different temperatures are used in extraction of gelatin but most of them are in the range from $50{ }^{\circ} \mathrm{C}$ to $60^{\circ} \mathrm{C}$. Temperatures from $45^{\circ} \mathrm{C}$ to $60^{\circ} \mathrm{C}$ can enhance bond formation within molecules between strands and therefore gelatin with stronger crystallization ability can be obtained. However, temperatures above 60 ${ }^{\circ} \mathrm{C}$ lead to broken chains within the particles giving weaker gelatin ability. Lower extraction temperatures, on the other hand, lead to low yields. The higher yield percent of the gelatin is obtained at moderate temperature.

In conclusion, the optimum condition for obtaining higher bloom strength around 150 bloom with an average molecular weight of $20000-25000 \mathrm{~g} \mathrm{~mol}^{-1}$ or 20-25 kilo Daltons was $4 \% \mathrm{w} / \mathrm{v} \mathrm{NaOH}, 4$ hours contact time, 250 rpm at $50{ }^{\circ} \mathrm{C}$. After that, characterization of the extracted gelatin was investigated chemically and instrumentally to check suitability for industrial or biomedical application.

\section{Characterization of Extracted Gelatin}

There is increasing attention in the extraction process of gelatin and its derivatives due to the rising tendency to use gelatin to replace synthetic agents in various industrial processes, which results in a greater approval of the by-products from animal slaughter. Gelatin's characteristics depend on the raw material and the extraction conditions, which subsequently determine its application. Gelatin has a wide range of applications in the food, pharmaceutical, cosmetic and photographic industries, among others; also gelatin quality is highly affected by physico-chemical characteristics, not only by species and tissue extract, but also by processing methods [27].

The properties of extracted gelatin samples from different alkalis are showed in Table 5.

Table 5: The properties of extracted gelatin

\begin{tabular}{ccccccc}
\hline $\begin{array}{c}\text { Extraction } \\
\text { Material }\end{array}$ & Color & $\begin{array}{c}\text { Moisture } \\
\text { Content \% }\end{array}$ & $\begin{array}{c}\text { Ash } \\
\text { Content \% }\end{array}$ & $\begin{array}{c}\text { Nitrogen } \\
\text { Content \% }\end{array}$ & $\begin{array}{c}\text { Fat } \\
\text { Content \% }\end{array}$ & Turbidity \\
\hline $\mathrm{NaOH}$ & Brown & $5.5 \pm 0.5$ & $4.5 \pm 0.6$ & $13.5 \pm 0.8$ & $0.45 \pm 0.03$ & 72 \\
$\mathrm{KOH}$ & Brown & $5.1 \pm 0.4$ & $5.4 \pm 0.4$ & $11.6 \pm 0.5$ & $0.40 \pm 0.02$ & 45 \\
$\mathrm{LiOH}$ & Brown & $4.7 \pm 0.6$ & $5.3 \pm 0.5$ & $10.9 \pm 0.7$ & $0.42 \pm 0.03$ & 101 \\
\hline
\end{tabular}

Mean Value \pm SD triplicate analysis, All the percentage represented in a dry basis except for moisture.

From Table 5 it is clear that the moisture content of all extracted gelatin from three alkalis was from 4 to $5.5 \%$ with the highest value for $\mathrm{NaOH}$ and lower value with $\mathrm{LiOH}$. The ash content was in the range from 4-6\%. However the nitrogen content has a high value $14 \%$ in case of $\mathrm{NaOH}$ and lower value in case of $11 \%$ in case of $\mathrm{LiOH}$. The gelatin extracted from the $\mathrm{LiOH}$ is more turbid than the others extracted gelatin from $\mathrm{NaOH}$ and $\mathrm{KOH}$ and the fat content from all the extracted gelatin was in range $0.39-0.45 \%$.

\section{FTIR Analysis of Extracted Gelatin}

Figure 1 and Table 6 show a typical FTIR spectrum for extracted gelatin at $50{ }^{\circ} \mathrm{C}$ using $4 \% \mathrm{w} / \mathrm{v}$ of different alkalis which completely resemble each other, taking $\mathrm{NaOH}$ and $\mathrm{KOH}$ solution with bloom $150 \mathrm{~g}$ as example. It displays three major peak regions noticeable as $1^{\text {st }}$ region $\left(3600-2700 \mathrm{~cm}^{-1}\right), 2^{\text {nd }}$ region $\left(1900-900 \mathrm{~cm}^{-1}\right)$, and $3^{\text {rd }}$ region $\left(400-900 \mathrm{~cm}^{-1}\right)$. The regions are specifying to the bonds as amide $\mathrm{A}$ and $\mathrm{B}$; also amide I, II and III; and amide IV, V and VI.

The FTIR spectrum shows characteristic transmittance peaks of the chemical functional groups of the gelatin in Figure 1 and Table 6 . The gelatin fibril found to be broadening and a slight shift to lower wave number of the amide $A$ peak, so associated with increased inter-molecular interactions of gelatin. The absorbance bands are identified as follows: a strong and broad overlapping band in the range of $3600-3300 \mathrm{~cm}^{-1}$ was assigned to $\mathrm{NH}$ bond in 
the peptide group of collagen and protein and for the $\mathrm{OH}$ of carboxylic group in the protein, the bands at 2938, $2877 \mathrm{~cm}^{-1}$ are from $-\mathrm{CH} 3$ and $-\mathrm{CH} 2$ stretching vibrations for the gelatin. The strong band at $1646,1652 \mathrm{~cm}^{-1}$ is due to $\mathrm{C}=0$ overlapping between carbonyl groups of gelatin, the bands at $1335 \mathrm{~cm}^{-1}$ and $1433 \mathrm{~cm}^{-1}$ are due to $-\mathrm{CH} 3$ and $-\mathrm{CH} 2$ bending vibration. The band at $1225 \mathrm{~cm}^{-1}$ was assigned to $\mathrm{NH}$ bending vibration of the amide group and the band at 1174, 1051 $\mathrm{cm}^{-1}$ is attributed to the strong $\mathrm{C}-\mathrm{O}-\mathrm{C}$ of amide bond in gelatin stretching vibrations, the bands at $987 \mathrm{~cm}^{-1}, 969 \mathrm{~cm}^{-1}, 695 \mathrm{~cm}^{-1}$ are the skeletal stretch $\mathrm{C}-\mathrm{C}$ - and $\mathrm{CH}$ out off plane. For the region from 750 to $500 \mathrm{~cm}^{-1}$ especially for extracted gelatin by $\mathrm{KOH}$, the C-S stretching mode is generally was observed related to cysteine and cystine [29]. Also, another characteristic skeletal deformation is due to the $\mathrm{C}-\mathrm{S}-\mathrm{H}$ and $\mathrm{O}=\mathrm{C}-\mathrm{S}$ out of plane bending appears at $400-500 \mathrm{~cm}^{-1}$.

Table 6: FTIR spectra and assignments of extracted gelatin

\begin{tabular}{lcc}
\hline Region & \multicolumn{2}{c}{ Extracted gelatin } \\
& Peak wave number cm ${ }^{-1}$ & Assignment \\
\hline Amide A & 3500 & NH stretch \\
& 3422 & OH stretch \\
& 2936 & $\mathrm{CH}$ asymmetrical stretch \\
& 2850 & $\mathrm{CH}$ 2 symmetrical stretch \\
Amide I & 1647 & $\mathrm{C}=\mathrm{O}$ stretch coupled with COO- \\
Amide II & 1524 & $\mathrm{NH}$ bend coupled C-N stretch \\
& 1455 & CH2 bend \\
Amide III & 1331 & $\mathrm{CH}$ bend, CH2 wagging of proline \\
& 1246 & NH bend \\
Amide IV & 1047 & C-O stretch \\
Amide V & 863 & CH out off plane, skeletal stretch \\
Amide VI & 687 & $\mathrm{CH}$ out off plane, skeletal stretch \\
\hline
\end{tabular}




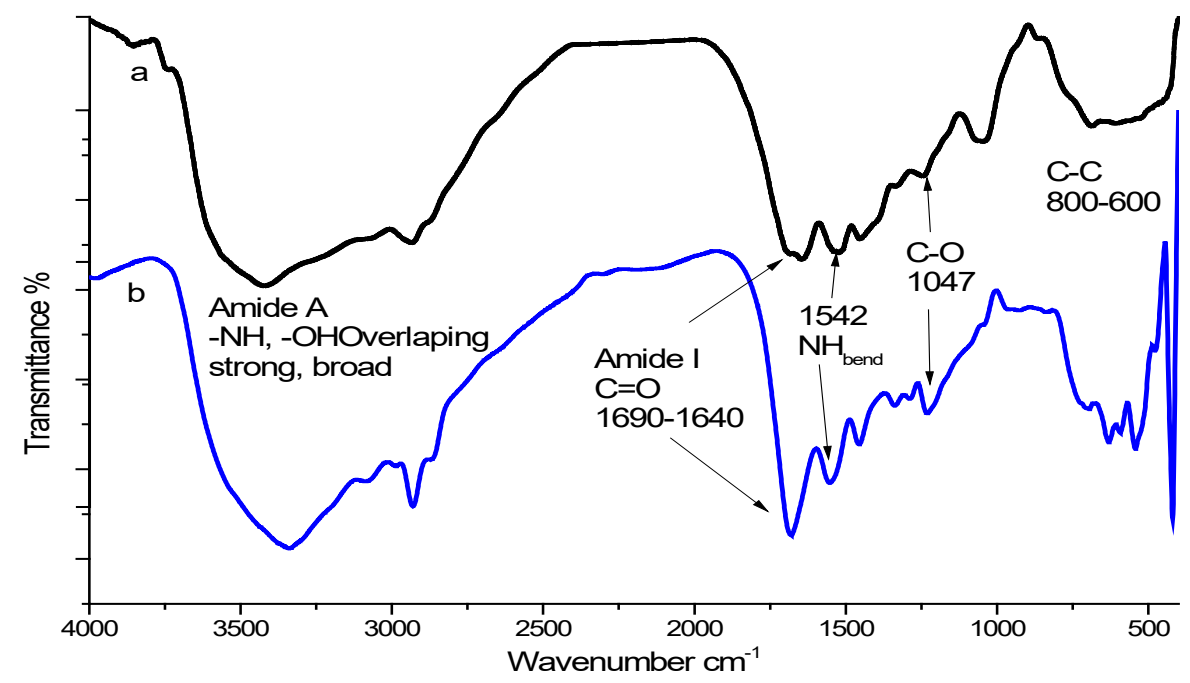

Figure 1. FTIR spectra of extracted gelatin with different alkalis: (a) $\mathrm{NaOH}$, (b) $\mathrm{KOH}$

All the previous detected peaks confirmed the structure of the extracted gelatin. The results obtained are in similarity in the literature [30].

\section{Dynamic Light Scattering (DLS)}

DLS can be considered a main tool to understand and verify models pertaining to the dynamics of biopolymers (gelatin) in dilute solution. It allows determining the size and hydrodynamic radius of biopolymers molecule in solution. As shown in Figure 2, the particle size distribution of gelatin which dispersed in aqueous medium presence relative particle diameter measurement distribution over narrow range from 0.45-1.6 $\mu \mathrm{m}$ with percentage more than $90 \%$ of particles by volume distribution. Low polydispersity, narrow distribution of particle size $(870 \mathrm{~nm})$ of gelatin indicated to the ability to form homogenized distribution of blended film gelatin, which gives gelatin film a range of application from few $\mu \mathrm{m}$ as packaging films.

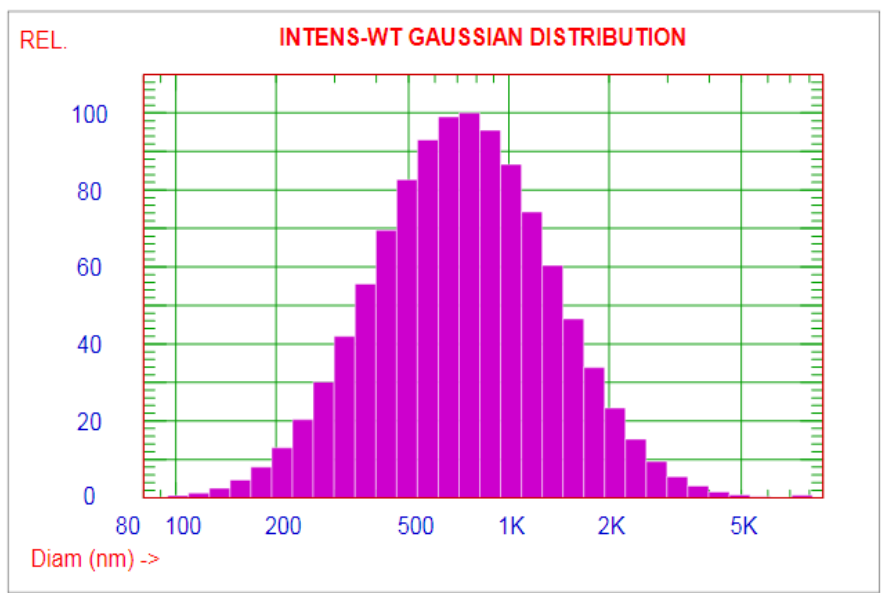

Figure 2. DLS image of particle size distribution of extracted gelatin with different ratios

\section{Amino Acids of Extracted Gelatin at Optimum Condition}

The amino acid composition of the gelatin extracted from white leather shavings (WLS) were presented in Table 7. The experimental results showed that under the conventional acidic hydrolysis conditions, complete hydrolysis of the white leather shavings (WLS) was proceeded with yield of 16 amino acids as revealed in Table 7. It was observed that, all of asparagines and glutamine are completely hydrolyzed to aspartic and glutamic acids, respectively. It is difficult to 
determine cysteine by acid hydrolysis and also tryptophan is completely damaged. Glutamic acid reaches the maximum amount of $20 \%$ while, aspartic acid and lysine reach to $10 \%$. Tyrosine is partially hydrolyzed and trace amounts are present in the hydrolysate, low amount of serine and threonine due to partial hydrolysis of about 3 and $4 \%$, respectively. The results obtained match with the literature [31].

Table 7: Amino acids composition (\%) of the extracted gelatin

\begin{tabular}{cccc}
\hline Amino Acids & $\%$ & Amino Acids & $\%$ \\
\hline Aspartic Acid & 10.35 & Leucine & 3.54 \\
Threonine & 3.93 & Isoleucine & 6.57 \\
Serine & 3.72 & Phenylalanine & 2.57 \\
Glutamic Acid & 19.78 & Tyrosine & 4.04 \\
Glycine & 3.86 & Histidine & 3.78 \\
Alanine & 3.76 & Lysine & 10.56 \\
Valine & 4.63 & Arginine & 4.66 \\
Methionine & 2.82 & Proline & 9.06 \\
$\mathrm{NH}_{4}^{+}$ & 2.16 & & \\
\hline
\end{tabular}

X-Ray Fluorescence Spectrometric Analysis of Extracted Gelatin

XRF study was carried out to determine the elemental constituents of extracted gelatin from white leather shavings by $4 \% \mathrm{w} / \mathrm{v}$ of different alkalis.

Table 8: XRF analysis of extracted gelatin at $4 \% \mathrm{w} / \mathrm{v}$ of different alkalis

\begin{tabular}{cccc}
\hline Main constituents & $(\mathrm{NaOH}), \mathrm{Wt} . \%$ & $(\mathrm{KOH}), \mathrm{Wt} \%$ & $(\mathrm{LiOH}), \mathrm{Wt} . \%$ \\
\hline $\mathrm{Si}$ & 0.154 & 0.139 & 0.186 \\
$\mathrm{Al}$ & 0.123 & 0.134 & 0.322 \\
$\mathrm{Fe}$ & 0.234 & 0.314 & 0.386 \\
$\mathrm{P}$ & 0.118 & 0.089 & 0.127 \\
$\mathrm{~S}$ & 1.35 & 0.98 & 1.168 \\
$\mathrm{Ca}$ & 1.166 & 1.120 & 1.230 \\
$\mathrm{Mg}$ & 0.048 & 0.050 & 0.039 \\
$\mathrm{Br}$ & -- & 0.030 & 0.003 \\
$\mathrm{Cu}$ & -- & ---- & ---- \\
$\mathrm{K}$ & 0.175 & 0.248 & 0.230 \\
$\mathrm{Na}$ & 0.256 & 0.129 & 0.316 \\
$\mathrm{Sr}$ & - & --- & --- \\
$\mathrm{Cl}$ & 1.333 & 1.230 & 1.654 \\
$\mathrm{Li}$ & -- & ---- & 0.123 \\
$\mathrm{Co}$ & -- & 0.001 & ---- \\
Loss On Ignition, LOI & 93.88 & 95.14 & 94.21 \\
\hline
\end{tabular}

From Table 8, it is obvious that, the percent of sulfur are $(1.35,0.98$ and 1.168$)$ for different alkalis $\mathrm{NaOH}, \mathrm{KOH}, \mathrm{LiOH}$, respectively. It is one of the highest values of element percent in gelatin. This is due to the cleavage of S-S bonds in cystine and cysteine by the differentalkalis. Other elements have few contributions with minor percentages. The higher value of $\mathrm{Na}$ in case of using $\mathrm{LiOH}$ is not logical but it may be related to apparatus analysis error. The higher value of Loss On Ignition related 
to the organic part of the extracted gelatin $(\mathrm{N}, \mathrm{C}, \mathrm{O}$, H) with percent $94 \%$ - $96 \%$.

\section{Thermal Gravimetric Analysis (TGA) of Extract- ed Gelatin}

TGA is a thermoanalytical technique that follows the change in weight of gelatin as a function of temperature. The response to thermal treatment depends on the structure and morphology of gelatin at each step. Thermal behaviours for gelatin extracted by $\mathrm{NaOH}, \mathrm{KOH}$ and $\mathrm{LiOH}$ from white shaving leather waste completely resemble and are presented in Figure 3.

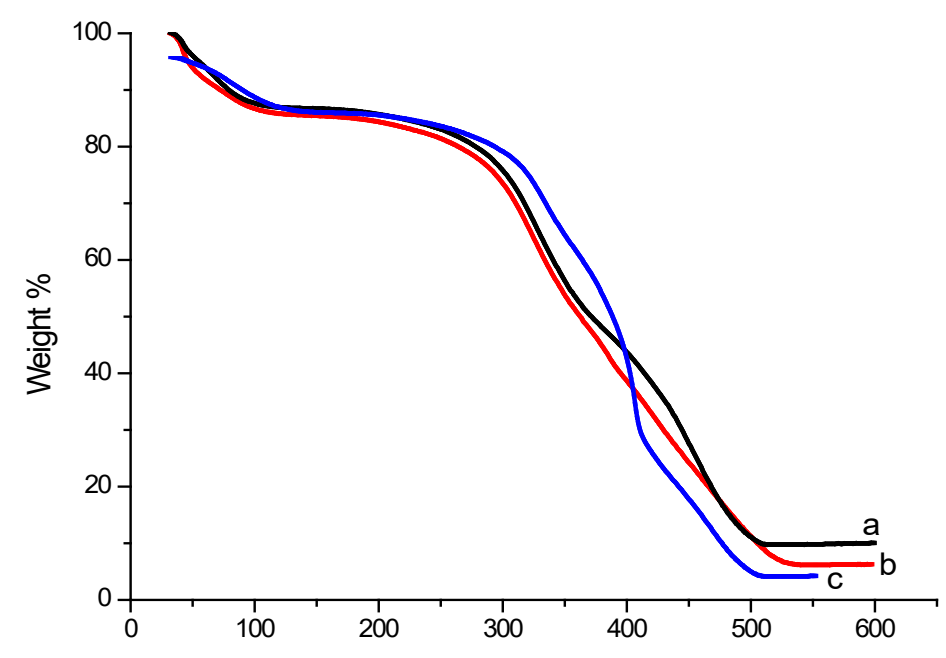

Figure 3. TGA of gelatin extracted by different alkalis (a) $\mathrm{NaOH}$, (b) $\mathrm{KOH}$ (c) $\mathrm{LiOH}$

It is clear that there are three main degradation stages: $1^{\text {st }}$ stage represents dehydration volatilization of low molecular weight substances and moisture. The $2^{\text {nd }}$ stage is the main degradation stage and the third stage is the carbonization stage. The gelatin sample extracted by different alkalis from WLS has an initial weight loss of about $12 \%$ at temperature between $50-127{ }^{\circ} \mathrm{C}$ due to the evaporation of water included in gelatin. There is a gradually decreased in the weight loss of the gelatin which reaches to $60 \%$ at temperature between 130 $440{ }^{\circ} \mathrm{C}$ due to burning of hydrocarbon chain of the gelatin chain. The $3^{\text {rd }}$ peak at $440-600{ }^{\circ} \mathrm{C}$ included the degradation of the rest of gelatin with a weight loss $19 \%$. After $600{ }^{\circ} \mathrm{C}$, the ash formed with about $9 \%$ of the initial weight. The results obtained are comparable and similar with the literature $[32,33]$.

\section{Differential Scanning Calorimetry (DSC)}

DSC analysis gives information about the glass transition behavior, $\mathrm{T}_{\mathrm{g}}$ of the extracted gelatin. Commonly, If $T_{g}$ of gelatin lies below room temperature, the gelatin films be more flexible and good elastomers. If $T_{g}$ of gelatin above room temperature the gelatin films takes rigid and brittle behavior. Thus, known information of $\mathrm{T}_{\mathrm{g}}$ is important in the selection of materials for various applications.

The slow traditional DSC scan at $10^{\circ} \mathrm{C} /$ min gives broadening endothermic peak that is observed from almost $-100{ }^{\circ} \mathrm{C}$ up to $200{ }^{\circ} \mathrm{C}$ in extracted gelatin samples (Figure 4). For regularity, the three thermal transitions of gelatin experimental in increasing order of temperature and will be referred to as $T_{g}$ (glass transition) $\backslash$ $T_{m}$ (melting) $\backslash T_{i}$ (isomerization), $T_{g}$ in the range of $40-50{ }^{\circ} \mathrm{C}$ and a melting peak $\left(\mathrm{T}_{\mathrm{m}}^{\mathrm{g}}\right)$ in the range of $133-144^{\circ} \mathrm{C}$ and melting enthalpy (normalized per unit mass) of $33 \mathrm{~J} / \mathrm{g}$. The results obtained match with the literature [34]. 


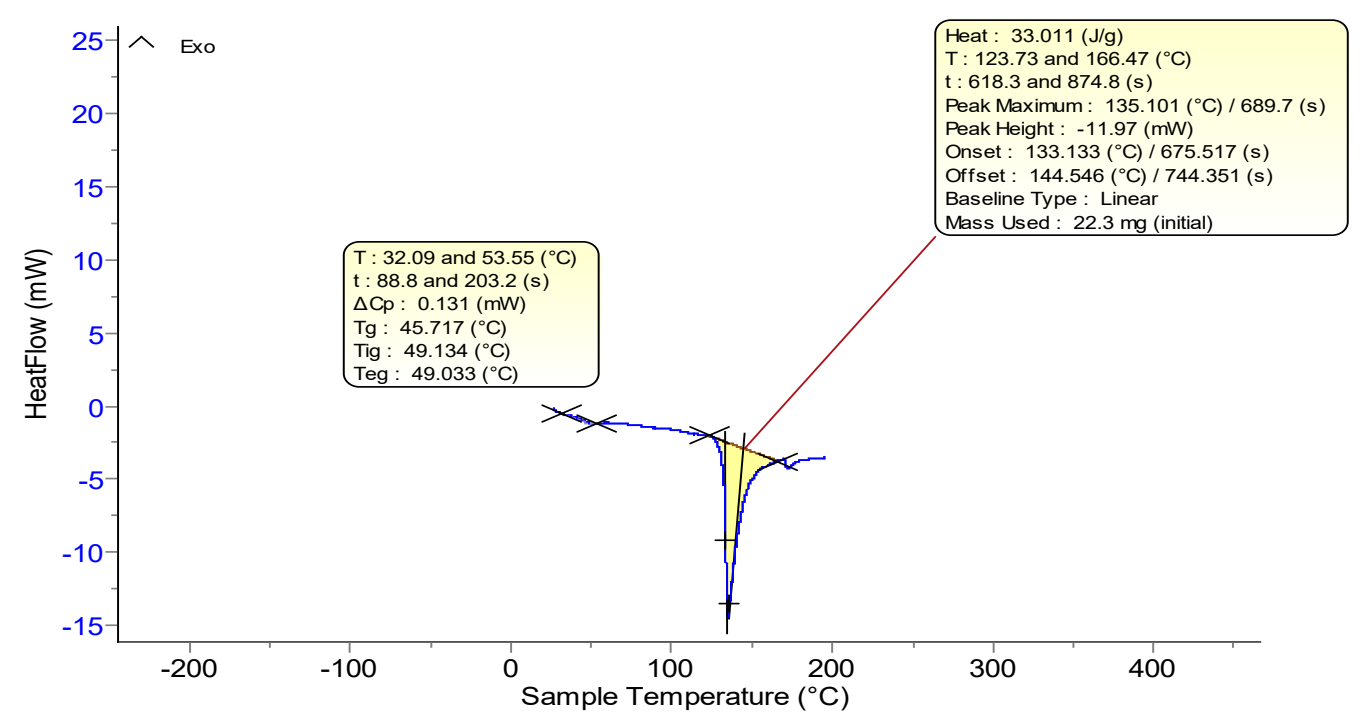

Figure 4. Differential scanning calorimetry (DSC) thermograms of extracted gelatin

\section{Scanning Electron Microscope (SEM) for White Leather Shaving and Extracted Gelatin with Different Alkalis}

Surface area morphology and microstructure of gelatin are recognized as vital tools for understanding its industrial, chemical and biomedical applications [35]. Figure 5 shows SEM images of white leather shavings, extracted gelatin with different alkalis at $10000 \mathrm{x}$ magnifications. The white leather shavings had a striped fiber bundle with irregularly filamentous

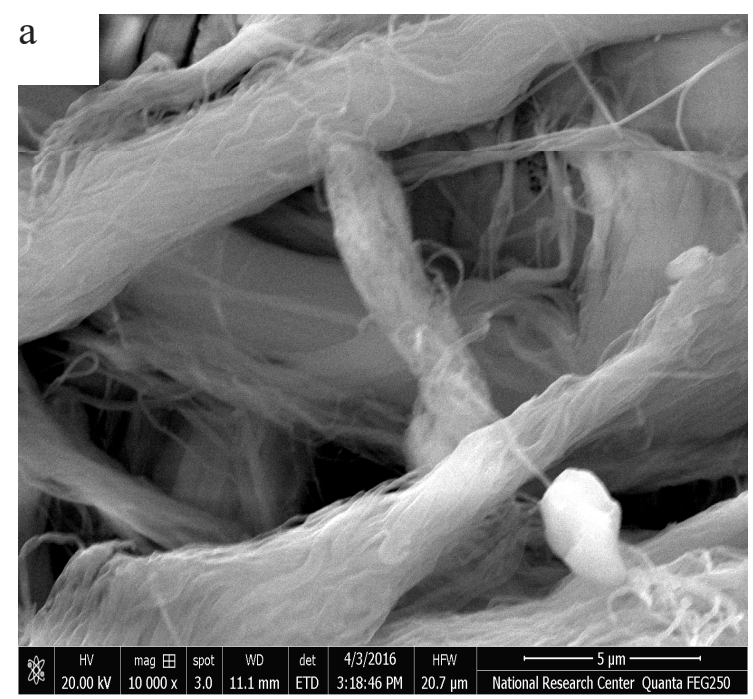

shape Figure 5(a), while the extracted gelatin from different alkalis showed pores with flake shape Figure $5(b-d)$. The collagen extracted from alkalis had a complex fibril form, related to the higher wet-ability, i.e. the ability to be adsorbed and be soluble in water $[36,37]$. Therefore, extracted gelatin is used as a hydrating agent in field of cosmetics. As described by the comparatively well-distributed pore structure might be suitable for biomedical application as mentioned by many researchers [38].

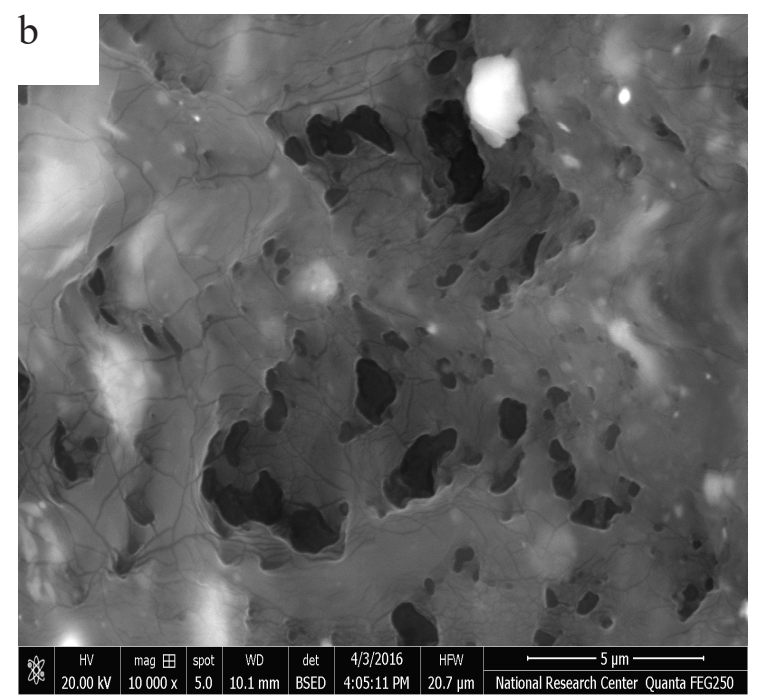



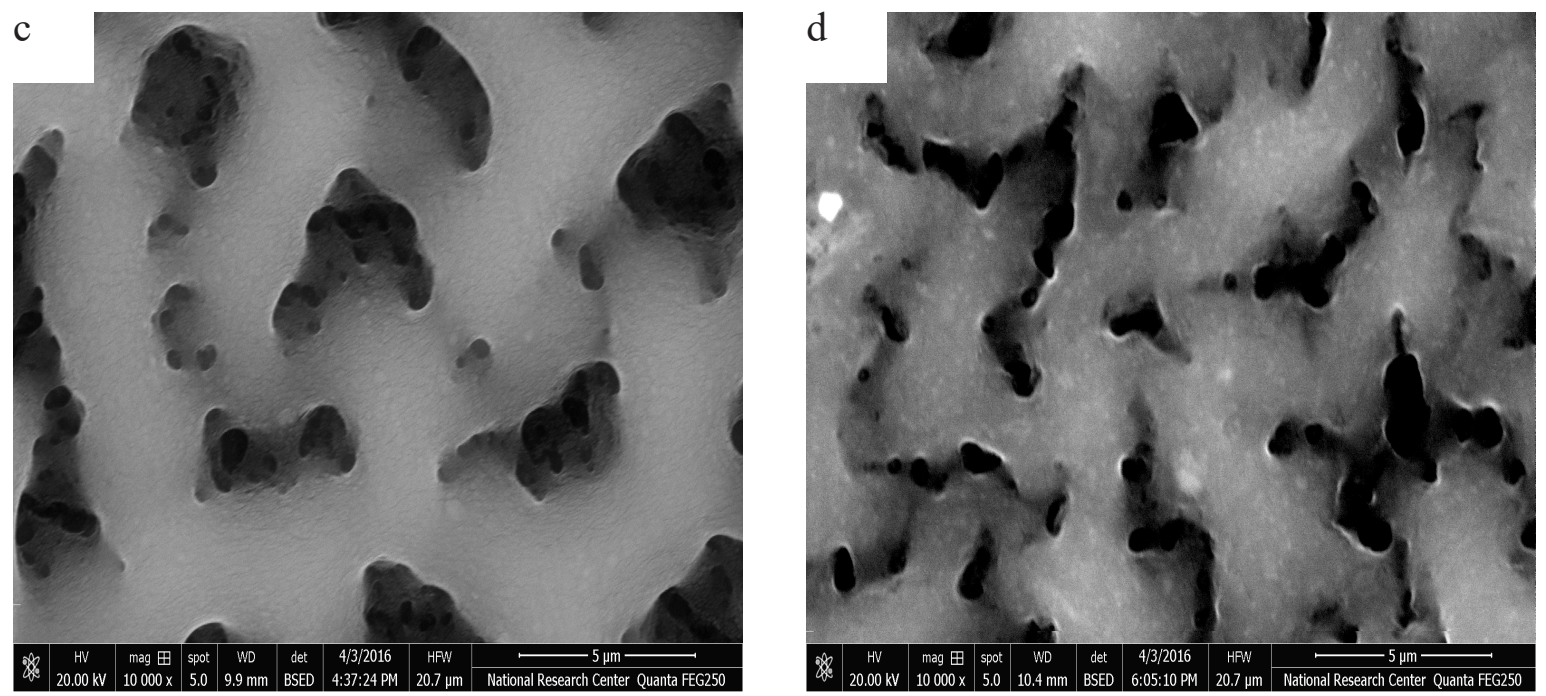

Figure 5. SEM images of a) white leather shavings; and extracted gelatin with different alkalis: b) $\mathrm{NaOH}$; c) $\mathrm{KOH}$; d) $\mathrm{LiOH}$

\section{CONCLUSION}

The aim of our article is to obtain high bloom gelatin from white leather shavings via combining the fields of leather technology and waste management technology for enhanced utilization of leather waste. Chemical treatments of white solid wastes by partial hydrolysis of wastes using different alkalis and different factors affecting hydrolysis such as alkalis concentration, contact time and temperature were studied. The system included preparing gelatin from white leather waste, isolating collagen protein from white leather waste by extracting method and characterization of extracted gelatin. The method verified that the leather wastes can be successfully processed to the powder gelatin products. It was found that the optimum conditions to obtain high bloom gelatin strength from white shaving leather wastes around 150 bloom are $4 \% \mathrm{w} / \mathrm{v} \mathrm{NaOH}, 4$ hours contact time, $250 \mathrm{rpm}$ at $50{ }^{\circ} \mathrm{C}$. FTIR spectra show the presence of functional groups of gelatin with different alkalis. TGA of extracted gelatin reaching to higher temperature $440{ }^{\circ} \mathrm{C}$, and glass transition temperature at $45^{\circ} \mathrm{C}$. SEM of the extracted gelatin from different alkalis showed pores with flake shape with the comparatively well-distributed pore structure that might be suitable for biomedical application especially in biodegradable packing materials.

\section{Acknowledgement}

This work was supported by The Science and Technology Development Fund (STDF), Young Research Program, (6088 Project) of Egypt.

\section{REFERENCES}

1. John Sundar, V., Gnanamani, A., Muralidharan, C., Chandrababu, N.K., Mandal, A.B., Rev Environ Sci Biotech, 2011, 10, 151-163, https://doi.org/10.1007/s11157-010-9223-6.

2. JohnSundar, V., Raghavarao, J., Muralidharan, C., Mandal, A.B., Crit Rev Environ Sci Technol, 2011, 41, 2048-2075, https://doi.org/10.1080 /10643389.2010.497434.

3. Beltrán-Prieto, J.C., Veloz-Rodríguez, R., PérezPérez, M.C., Navarrete-Bolaños, J.L., VázquezNava, E., Jiménez-Islas, H., Botello-Álvarez, J.E., Chem Ecol, 2012, 28, 89-102, https://doi. org/10.1080/02757540.2011.628016.

4. Gousterova, A., Nustorova, M., Christov, P., Nedkov, P., Neshev, G., Vasileva-Tonkova, E., World J Microbiol Biotechnol, 2008, 24, 2647-2652, https://doi.org/10.1007/s11274008-9788-1. 
5. Nishad Fathima, N., Aravindhan, R., Raghava Rao, J., Nair, B.U., J Chem Technol Biotechnol, 2009, 84, 1338-1343, https://doi.org/10.1002/jctb.2186.

6. Mukhopadhyay, N., Saha, N., Saha, L., Saha, P., Kolomaznik, K., J Am Leather Chem As, 2004, 99, 449-456.

7. Ozgunay, H., Colak, S., Mutlu, M., Akyuzet, F., Polish J of Environ Stud, 2007, 16, 867-873.

8. Boran, G., Regenstein, J.M., Adv Food Nutr Res, 2010, 60, 119-143, https://doi.org/10.1016/ S1043-4526(10)60005-8.

9. Cot, J., Marsal, A., Manich, A., Celma, P., Cabeza, L., Labastida, L., Lopez, J., Salmeron, J., J Soc Leath Tech Ch, 2003, 87, 91-99.

10. $\mathrm{Mu}, \mathrm{C} .$, Lin, W., Zhang, M., Zhu, Q., Waste Manag, 2003, 23, 835-843, https://doi. org/10.1016/S0956-053X(03)00040-0.

11. Vert, M., Doi, Y., Hellwich, K.H., Hess, M., Hodge, P., Kubisa, P., Rinaudo, M., Schue, F., Pure Appl Chem, 2012, 84, 377-410, https:// doi.org/10.1351/PAC-REC-10-12-04.

12. Konermann, L., Protein Unfolding and Denaturants, eLS. Chichester, UK: John Wiley \& Sons, Ltd. 2012.

13. Langmaier, F., Sivarova, J., Kolomaynik, K., Mladek, M., J Therm Anal Calorim, 2004, 76, 1015-1023, https://doi.org/10.1023/ B:JTAN.0000032286.85251.66.

14. Langmaier, F., Mokrejs, P., Karnas, R., J Soc Leath Tech Ch, 2005, 90, 29-34.

15. Khatoon, M., Kashif, S., Saad, S., Umer, Z., Rasheed, A., J Waste Recycl, 2017, 2, 1-6.

16. Mariod, A.A., Adam, H.F., Acta Sci Pol Technol Aliment, 2013, 12, 2, 135-147.

17. Yang, H., Shu, Z., J Chem Pharm Res, 2014, 6, 2, 683-687.
18. Schmidt, M., Dornelles, P., Mello, O., Kubota, H., Mazutti, M., Kempka, P., Demiate, M., Int Food Res J, 2016, 23, 3, 913-922.

19. Kanagaraj, J., Velappan, K., Babu, C., Chandra, N., Sadulla, S., J Sci Ind Res, 2006, 65, 541-548.

20. Chen, Y., Guovin, L., Jia, Y., J Soc Leath Tech Ch, 2013, 97, 195-199.

21. Talapphet, N., Prommajak, T., Raviyan, P., Food and Applied Bioscience Journal, 2017, 5, 3, 132-148.

22. Dang, X., Shan, Y., Chen, H., Int J Biol Macromol, 2018, 107, 1023-1029.

23. Catalina, M., Attenburrow, G., Cot, J., Covington, A., Antunes, M., J App Poly Sci, 2011, 119, 2105-2111, https://doi. org/10.1002/app.32932.

24. Nur Hanani, Z.A., Roos, Y.H., Kerry, J.P., Int J Biol Macromol, 2014, 71, 94-102, https:// doi.org/10.1016/j.ijbiomac.2014.04.027.

25. Shaikh, M.A.A., Deb, A.K., Akter, E., Ferdous, T., Mia, M.A.S., J Sci Innov Res, 2017, 6, 4, 138-141.

26. Duan, R., Zhang, J., Liu, L., Cui, W., Regenstein, J.M., Food Chem, 2018, 239, 464-469, https:// doi.org/10.1016/j.foodchem.2017.06.145.

27. Gómez-Guillén, M.C., Giménez, B., LópezCaballero, M.E., Montero, M.P., Food Hydrocoll, 2011, 25, 8, 1813-1827, https:// doi.org/10.1016/j.foodhyd.2011.02.007.

28. Lin-Vien, D., Colthup, N., Fateley, W., Grasselli, J., The Handbook of Infrared and Raman Characteristic Frequencies of Organic Molecules, Elsevier, chapter 14, p. 234, 1991.

29. Gudmunässon, M., Hafsteinasson, H., J Food Sci, 1997, 62, 37-39, https://doi. org/10.1111/j.1365-2621.1997.tb04363.x.

30. Al-Saidi, S., Al-Alawi, A., Rahman, S. Guizani, N., Int Food Res J, 2012, 19, 3, 1167-1173. 
31. Fountoulakis, M., Lahm, H.W., J ChromatogrA, 1998, 826, 109-134, https://doi.org/10.1016/ S0021-9673(98)00721-3.

32. Binsi, P.K., Nayak, N., Sarkar, P.C., Joshy, C.G., Ninan, G., Ravishankar, C.N., J Food Sci Technol, 2017, 54, 518-530, https://doi. org/10.1007/s13197-017-2496-9.

33. Mukherjee, I., Rosolen, M., Il Therm Anal Calorim, 2013, 114, 1161-1166.

34. Kasapis, S., Sablani, S.S., Int J Biol Macromol, 2005, 36, 71-78, https://doi.org/10.1016/j. ijbiomac.2005.03.010.

35. Zhang, Q., Wang, Q., Lv, S., Lu, J., Jiang, S., Regenstein, J.M., Lin, L., Food Biosci, 2016, 13, 41-48, https://doi.org/10.1016/j. fbio.2015.12.005.
36. Veeruraj, A., Arumugam, M., Balasubramanian, T., Process Biochem, 2013, $48,10,1592-1602$.

37. Veeruraj, A., Arumugam, M., Ajithkumar, T., Balasubramanian, T., J Mater Sci Mater Med, 2012, 23, 1729-1738, https://doi. org/10.1007/s10856-012-4650-2.

38. Yue, K., Trujillo-de-Santiago, G., Alvarez, M.M., Tamayol. A., Annabi, N., Khademhosseini, A., Biomaterials, 2015, 73, 254-271, https://doi. org/10.1016/j.biomaterials.2015.08.045.

(C) 2018 by the author(s). Published by INCDTPICPI, Bucharest, RO. This is an open access article distributed under the terms and conditions of the Creative Commons Attribution license (http:// creativecommons.org/licenses/by/4.0/). 